\title{
Burrow characteristics of the co-existing sibling species Mus booduga and Mus terricolor and the genetic basis of adaptation to hypoxic/hypercapnic stress
}

\author{
Sunita Singh*1,4, Nge Cheong ${ }^{2}$, Gopeshwar Narayan ${ }^{3}$ and T Sharma ${ }^{4}$
}

\begin{abstract}
Address: ${ }^{1}$ Department of Zoology, Mahila Mahavidyalaya, Banaras Hindu University, Varanasi - 221005, India, ${ }^{2}$ Bioprocessing Technology Centre, Clinical Research Centre, Department of Pediatrics, Faculty of Medicine, National University of Singapore - 119 260, Singapore, ${ }^{3}$ Department of Molecular and Human Genetics, Banaras Hindu University, Varanasi - 221005, India and ${ }^{4}$ Cytogenetics Laboratory, Department of Zoology, Banaras Hindu University, Varanasi - 221005 , India
\end{abstract}

Email: Sunita Singh* - sunitas@bhu.ac.in; Nge Cheong - cheong_NGE@bti.a-star.edu.sg; Gopeshwar Narayan - gnarayan@bhu.ac.in; T Sharma - tsharma123@yahoo.co.in

* Corresponding author

Published: 9 April 2009

BMC Ecology 2009, 9:6 doi:10.1186/1472-6785-9-6
Received: 26 November 2008

Accepted: 9 April 2009

This article is available from: http://www.biomedcentral.com/l472-6785/9/6

(C) 2009 Singh et al; licensee BioMed Central Ltd.

This is an Open Access article distributed under the terms of the Creative Commons Attribution License (http://creativecommons.org/licenses/by/2.0), which permits unrestricted use, distribution, and reproduction in any medium, provided the original work is properly cited.

\begin{abstract}
Background: The co-existing, sibling species Mus booduga and Mus terricolor show a difference in sitepreference for burrows. The former build them in flat portion of the fields while the latter make burrows in earthen mounds raised for holding water in cultivated fields. In northern India which experiences great variation in climatic condition between summer and winter, $M$. booduga burrows have an average depth of $4 \mathrm{l} \mathrm{cm}$, as against $30 \mathrm{~cm}$ in southern India with less climatic fluctuation.

M. terricolor burrows are about $20 \mathrm{~cm}$ deep everywhere. The three chromosomal species $M$. terricolor I, II and III have identical burrows, including location of the nest which is situated at the highest position. In contrast, in $M$. booduga burrows, the nest is at the lowest position.

Results: The nest chamber of $M$. booduga is located at greater depth than the nest chamber of $M$. terricolor. Also, in the burrows of $M$. booduga the exchange of air takes place only from one side (top surface) in contrast to the burrows of $M$. terricolor where air exchange is through three sides. Hence, $M$. booduga lives in relatively more hypoxic and hypercapnic conditions than $M$. terricolor.

We observed the fixation of alternative alleles in $M$. booduga and $M$. terricolor at Superoxide dismutase- $I$ (Sod-I), Transferrin (Trf) and Hemoglobin beta chain ( $\mathrm{Hbb})$ loci. All the three are directly or indirectly dependent on oxygen concentration for function. In addition to these, there are differences in burrow patterns and site-preference for burrows suggesting difference in probable adaptive strategy in these coexisting sibling species.

Conclusion: The burrow structure and depth of nest of the chromosomal species M. terricolor I, II and III are same everywhere probably due to the recency of their evolutionary divergence. Moreover, there is lack of competition for the well-adapted 'microhabitats' since they are non-overlapping in distribution. However, the co-existing sibling species $M$. booduga and $M$. terricolor exhibit mutual "exclusion" of the 'microhabitats' for burrow construction. Thus, location, structure and depth of the burrows might have been the contributory factors for selection of alternative alleles at three loci Sod-I, Trf and Hbb, which reflect difference in probable adaptive strategy in $M$. booduga and $M$. terricolor.
\end{abstract}




\section{Background}

Mus booduga (Gray 1837) and Mus terricolor Blyth, 1851 are the indigenous pygmy field mice of India and are highly interesting for evolutionary studies. They are morphologically alike and were considered conspecific until Matthey and Petter [1] discovered that they were two sibling species, primarily based on their divergent karyotypes. These co-existing, sibling species are closely allied to the house mouse Mus musculus belonging to a sister lineage. They are found in abundance in cultivated fields being a major pest infesting mainly rice and wheat fields. These field mice have $2 n=40$ chromosomes as in other Mus species. M. booduga has the same karyotype throughout its distribution with all acrocentric chromosomes in the complement, identical to that of M. musculus. The karyotype of $M$. terricolor, on the other hand, is distinct due to the presence of large submetacentric $\mathrm{X}$ and large acrocentric $\mathrm{Y}$ chromosomes. In addition, different apparently non-overlapping populations of $M$. terricolor possess divergent karyotypes showing variation in the number of autosomal heterochromatic large short arms established in homozygous condition [2,3]. A multidimentional investigation carried out over the years in our laboratory at Varanasi revealed recency of evolutionary differentiation of the three chromosomal species of $M$. terricolor which however have developed both pre-mating and almost complete post-zygotic isolations [3-7].

We have earlier analysed 20 enzymatic and nonenzymatic loci in Mus booduga-terricolor complex as well as Mus musculus tytleri [6] for genetic variations. Among 20 loci only three loci (hemoglobin beta-chain, transferrin and superoxide dismutase) showed adaptive correlation. We have observed direct correlation of the difference in preference for sites for burrows in the fields and difference in depth of burrows and nest chamber position in the burrows of M. booduga and M. terricolor to the fixation of alternative alleles at three loci hemoglobin beta-chain (Hbb), transferrin (Trf) and superoxide dismutase (Sod-1) (whose functions are directly or indirectly dependent on oxygen concentration). The fixation of alternative alleles at these three loci, and the differences in their burrow patterns and location probably reflect adaptive strategy difference between the co-existing, sibling species.

\section{Results}

The season of breeding of both M. terricolor and M. booduga coincided with the harvesting of major crops, namely, rice and wheat. In southern India, where the difference in climatic conditions in summer is less-marked compared to other seasons, and availability of the crops is fairly continuous, breeding was observed almost throughout the year. In the north however, these mice were hardly traceable in the parched fields during hot summer months, but they were in abundance when rice and wheat were harvested in October/November and March/April. These pygmy field mice remain in burrows during day time and come to surface only at nights in search of food and mates.

\section{Burrow study}

A characteristic feature of live burrows was the presence of small mounds of minute damp soil pellets at the entrance. Larger mounds were seen at the entrance of breeding or family burrows with pups. Pups were found in globular nests padded with dried grass and straw. A study of 76, 14 and 73 litter of $M$. terricolor I, II and III, respectively showed that the litter size varied from 2 to 19 with a mean of 8 . Seven litters of $M$. booduga were examined and were found to be similar in size as in M. terricolor.

The presence of mice in burrows could be ascertained by the degree of freshness or wetness of pellets at the entrance. The entrance and particularly the exit of the burrows were camouflaged making them fairly inconspicuous. It was striking that $M$. terricolor constructed their burrows in the raised earthen mounds or bunds built for holding water in cultivated fields. The M. booduga burrows, on the other hand, were located in flat portions of the fields. The difference for preference of site for making burrows was found in northen as well as southern India. A total of 98 burrows of M. booduga (24 from Varanasi, 20 from Erode and Mysore and 54 from Chennai) and 194 burrows of the $M$. terricolor complex (83 of $M$. terricolor I from Varanasi, 13 of M. terricolor II from Mysore and 98 of M. terricolor III from Chennai) were excavated and studied. The burrows of M. booduga and M. terricolor had similarities in diameter $(2.5 \mathrm{~cm})$ of inlet and outlet tunnels, diameter $(13-14 \mathrm{~cm})$ of nest chamber, number of storage cell (usually one but not exceeding two in a burrow) and in having a single entrance (table 1, fig. 1).

The burrows of M. terricolor I, II and III showed more or less similar measurements and other features in different soil-types from northern and southern India. It was interesting that $M$. terricolor seem to prefer moist soils, and often one would come across tunnel of crabs by the side of M. terricolor burrows (fig. 1a). The average lengths of the inlet and outlet tunnels were almost equal being 45 $\mathrm{cm}$ (range: $30-76 \mathrm{~cm}$ ) and $50 \mathrm{~cm}$ (range: $40-70 \mathrm{~cm}$ ) respectively. The nest chamber was at an average $20 \mathrm{~cm}$ (range: $18-22 \mathrm{~cm}$ ) from the top surface which was markedly less deeper compared to the nest chamber in M. booduga burrows which was at an average depth of $41 \mathrm{~cm}$ (range: 38-45) in the alluvial and deltaic soils in the north and at $30 \mathrm{~cm}$ (range: $28-32 \mathrm{~cm}$ ) in the red and coastal alluvial soils in the south. The burrows in northen India therefore had longer and deeper tunnels; the inlet and outlet tunnels being $66 \mathrm{~cm}$ (range: 40-80 cm) and 77 $\mathrm{cm}$ (range: $30-90 \mathrm{~cm}$ ) as compared to shallower $46 \mathrm{~cm}$ 

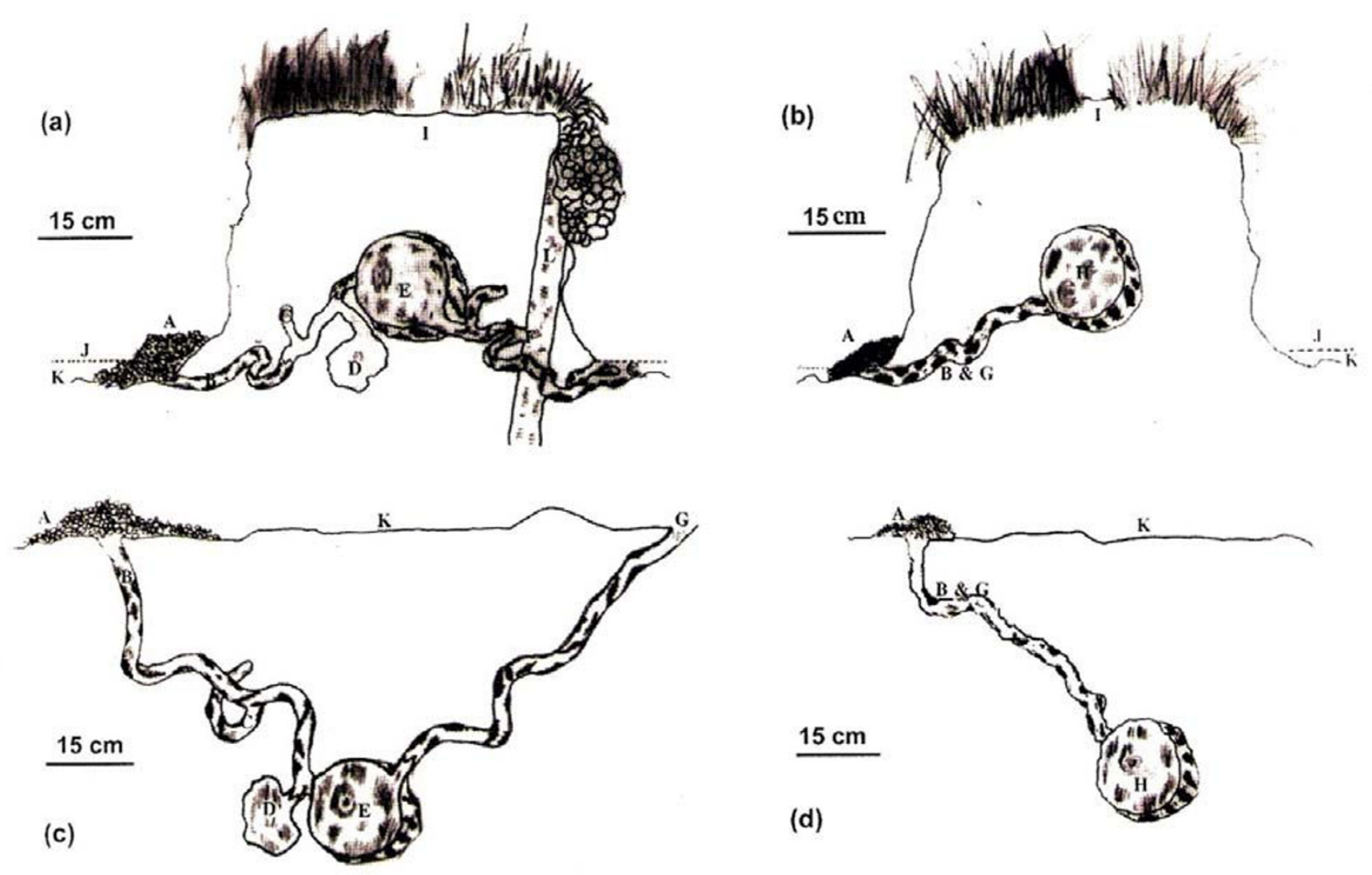

$$
\begin{aligned}
& A=\text { characteristic soil pellet } \\
& B=\text { inlet tunnel } \\
& C=\text { blind end tunnel } \\
& D=\text { storage cell }
\end{aligned}
$$

$E=$ nest
$F=$ outlet to crab's hole
$G=$ outlet tunnel
$H=$ resting chamber

$\mathrm{I}=$ bund

$\mathbf{J}=$ field water level

$\mathrm{K}=$ ground level

$\mathrm{L}=$ crab's hole in $\mathrm{a}$

Figure I

Diagrammatic representation of family (a) and male (b) burrows of $M$. terricolor; family (c) and male (d) burrows of $M$. booduga.

(range: $20-50 \mathrm{~cm}$ ) and $43 \mathrm{~cm}$ (range: $10-50 \mathrm{~cm}$ ) ones in southern India (table 1). Analysis of variance (ANOVA) shows high F-values indicating significant difference among taxa with respect to lengths of inlet and outlet tunnels and the depth of the nest chamber (table 1). Thus, the difference in location of the burrows and in position of the nest chamber, (which is at a level lower than the inlet and outlet tunnels in M. booduga whereas in M. terricolor it is situated above the levels of the inlet and outlet tunnels), would affect concentration of $\mathrm{O}_{2}$ and $\mathrm{CO}_{2}$ in the nest chambers of their burrows.

Besides the family burrows with females and pups, much simple burrows were also found which were occupied only by adult male. Excavation of 17 such burrows of both
M. terricolor (fig. 1b) and M. booduga (fig. 1d) showed that these had no separate outlet tunnels, storage cell or bluntend tunnel. The inlet tunnel of each species ended in a chamber resembling the nest chamber, but without bedding. The inlet tunnel was running downward from the entrance in case of M. booduga burrows whereas it was running upward in $M$. terricolor burrows. The sites for the male burrows were as for the family/breeding burrows.

\section{Electrophoretic analysis}

The sample size studied for the three loci Sod-1, Trf and $\mathrm{Hbb}$ varied from 11 to 28 . The allelic frequencies were 1.000 for the allele Sod $-1^{\mathrm{a}}$ in all the three chromosomal species M. terricolor I, II and III (table 2, fig. 2A lanes 5 to 10) and 1.000 for the alternative allele Sod- 1 b , which was 
Table I: Average burrow dimensions of Indian field pigmy mice.

\begin{tabular}{|c|c|c|c|c|c|}
\hline $\begin{array}{c}\text { Taxa } \\
\text { (no. of burrows) }\end{array}$ & $\begin{array}{l}\text { Length of inlet tunnel } \\
\quad \text { (Range) }( \pm \text { SD) }\end{array}$ & $\begin{array}{l}\text { Length of outlet tunnel } \\
\text { (Range) }( \pm \text { SD) }\end{array}$ & $\begin{array}{l}\text { Depth of Nest chamber } \\
\text { (Range) }( \pm \text { SD) }\end{array}$ & Diameter of nest & $\begin{array}{l}\text { Diameter of tunnel } \\
\text { (inlet and outlet) }\end{array}$ \\
\hline $\begin{array}{l}\text { M. booduga }(\mathrm{V}) \\
(24)\end{array}$ & $\begin{array}{c}66 \mathrm{~cm} \\
(40-80 \mathrm{~cm}) \\
( \pm 10.90)\end{array}$ & $\begin{array}{c}77 \mathrm{~cm} \\
(30-90 \mathrm{~cm}) \\
( \pm 15.30)\end{array}$ & $\begin{array}{c}41 \mathrm{~cm} \\
(38-45 \mathrm{~cm}) \\
( \pm 1.96)\end{array}$ & $13-14 \mathrm{~cm}$ & $2.5 \mathrm{~cm}$ \\
\hline $\begin{array}{l}\text { M. booduga (M) } \\
(74)\end{array}$ & $\begin{array}{c}46 \mathrm{~cm} \\
(20-50 \mathrm{~cm}) \\
( \pm 6.90)\end{array}$ & $\begin{array}{c}43 \mathrm{~cm} \\
(10-50 \mathrm{~cm}) \\
( \pm 9.92)\end{array}$ & $\begin{array}{c}30 \mathrm{~cm} \\
(28-32 \mathrm{~cm}) \\
( \pm 1.4 \mathrm{I})\end{array}$ & $13-14 \mathrm{~cm}$ & $2.5 \mathrm{~cm}$ \\
\hline $\begin{array}{l}\text { M. terricolor I } \\
\text { (83) }\end{array}$ & $\begin{array}{c}45 \mathrm{~cm} \\
(30-76 \mathrm{~cm}) \\
( \pm 10.70)\end{array}$ & $\begin{array}{c}50 \mathrm{~cm} \\
(40-70 \mathrm{~cm}) \\
( \pm 7.92)\end{array}$ & $\begin{array}{c}20 \mathrm{~cm} \\
(18-22 \mathrm{~cm}) \\
( \pm 1.44)\end{array}$ & $13-14 \mathrm{~cm}$ & $2.5 \mathrm{~cm}$ \\
\hline $\begin{array}{l}\text { M. terricolor II } \\
\text { (I3) }\end{array}$ & $\begin{array}{c}45 \mathrm{~cm} \\
(30-76 \mathrm{~cm}) \\
( \pm 14.00)\end{array}$ & $\begin{array}{c}50 \mathrm{~cm} \\
(40-70 \mathrm{~cm}) \\
( \pm 8.98)\end{array}$ & $\begin{array}{c}20 \mathrm{~cm} \\
(18-22 \mathrm{~cm}) \\
( \pm 1.53)\end{array}$ & $13-14 \mathrm{~cm}$ & $2.5 \mathrm{~cm}$ \\
\hline $\begin{array}{l}\text { M. terricolor III } \\
(98)\end{array}$ & $\begin{array}{c}45 \mathrm{~cm} \\
(30-76 \mathrm{~cm}) \\
( \pm 10.90)\end{array}$ & $\begin{array}{c}50 \mathrm{~cm} \\
(40-70 \mathrm{~cm}) \\
( \pm 7.99)\end{array}$ & $\begin{array}{c}20 \mathrm{~cm} \\
(18-22 \mathrm{~cm}) \\
( \pm 1.40)\end{array}$ & $13-14 \mathrm{~cm}$ & $2.5 \mathrm{~cm}$ \\
\hline ANOVA (F-value) & 19.84 & 50.86 & 1187 & - & - \\
\hline
\end{tabular}

markedly anodal, in M. booduga (table 2, fig. 2A lanes 1 to 4). In M. booduga the frequency of Trfa, which was much more anodal to $\operatorname{Trf}^{\mathrm{c}}$ and $\operatorname{Trf}^{\mathrm{d}}$ was 0.946 (table 2, fig. 2B lanes 1 to 4 ) and of $\operatorname{Trf}^{\mathrm{b}}$ it was 0.054 . The frequencies were $0.962,0.913$ and 0.904 for $\operatorname{Trf}^{\mathrm{c}}$ and $0.038,0.087$ and 0.096 for Trfd in M. terricolor I, II and III respectively (table 2, fig. 2B lanes 5 to 10). For heamoglobin beta chain (Hbb), in M. terricolor I, II and III, only allele Hbbp was present (table 2, fig. 2C lanes 5 to 10), but in M. booduga the frequency of Hbbp was very low being 0.034 whereas it was 0.966 for $\mathrm{Hbb}^{\mathrm{b}}$ (table 2, fig. 2C lanes 1 to 4 ).

\section{Discussion}

There are reports on nest construction in various Mus species mostly under laboratory conditions but very few in natural environments [reviewed in $[8,9]]$. Nest ranges from a simple pallet to a spherical enclosed type and the burrow structures vary from a simple system of M. m. musculus, M. m. domesticus and M. m. molossinus with shallow burrows of $18-20 \mathrm{~cm}$ to that of M. m. hortulanus which has the most complex of all Mus species with its nest chamber 30 to $40 \mathrm{~cm}$ deep in soil. The burrows of the coexisting $M$. booduga and M. terricolor are particularly interesting because of their site of construction. The position of the entrance and exit of the burrows of M. booduga is located at the highest level while their nest is at the lowest level (fig. 1). On the other hand, M. terricolor I, II and III have their nest at the highest level and the entrance and exit at the lowest level of the burrow (fig. 1). This difference is due to their location (in the raised bunds in case of M. terricolor I, II and III and below the flat field ground in case of M. booduga).

Low $\mathrm{O}_{2}$ (hypoxic) and high $\mathrm{CO}_{2}$ (hypercapnic) conditions have been reported in the occupied burrows of rodents, e.g., Spalax and Geomys [10-12] and also converging points of evidence show adaptive mechanisms of Spalax to the extreme conditions of hypoxia in its subterranean environment $[13,14]$. In the burrows of the Indian pygmy field mice too relatively less $\mathrm{O}_{2}$ and more $\mathrm{CO}_{2}$ could be present which would vary with depth, since it is known that proportion of $\mathrm{O}_{2}$ decreases and $\mathrm{CO}_{2}$ increases with increase in depth below ground level [14-18]. Since postpartum mating takes place in these mice, in the breeding season in the nest chambers litters of different age groups are often found in both $M$. booduga and M. terricolor burrows. It is quite common that suckling females are already gravid. Increase in the number of individuals in the nest chambers would further affect $\mathrm{O}_{2}$ and $\mathrm{CO}_{2}$ concentrations. The nest chambers are located at greater depth in $M$. booduga compared to that of $M$. terricolor and exchange of air takes place from only one surface (top surface) in the M. booduga burrows built in flat fields. In the M. terricolor burrows, on the other hand, exchange of air takes place from three sides of the raised mounds or bunds where they build their burrows. These differences should affect $\mathrm{O}_{2}$ and $\mathrm{CO}_{2}$ levels and consequently, the burrows and nest chambers of $M$. terricolor would be relatively more aerated than that of M. booduga. Apparently, M. booduga lives in more hypoxic and hypercapnic conditions compared to M. terricolor types I, II and III. F-values obtained by ANOVA also indicate significant difference in the burrow dimensions. Interestingly, very high F-value for depth of the tunnel (table 1) supports significant difference in the level of depth of burrows of M. budooga and M. terricolor reflecting difference in hypoxic/hypercapnic conditions among burrows.

Hypoxic/hypercapnic conditions known to be lethal to other mammals had no visible effect on these Indian pygmy field mice as also reported in case of subterranean mole rats. However, the evidence shows structural differ- 


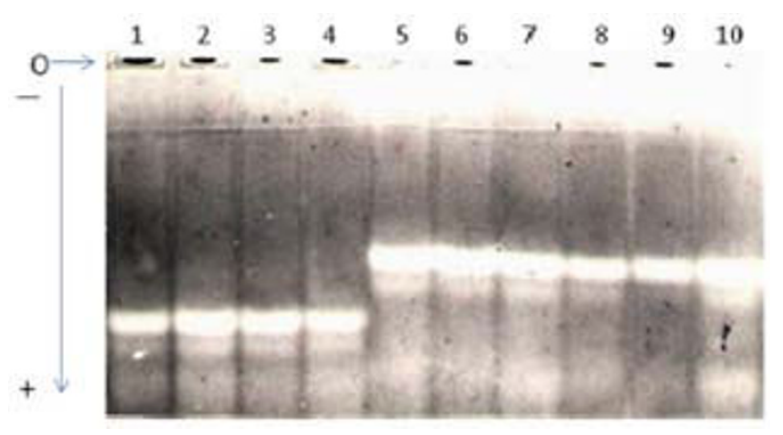

A

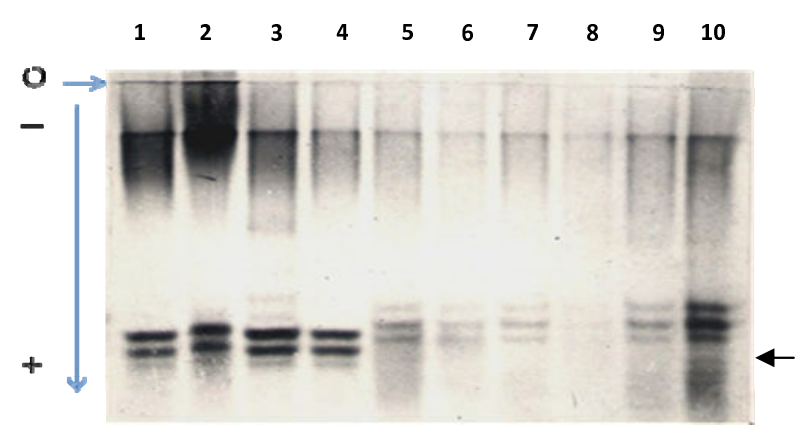

B

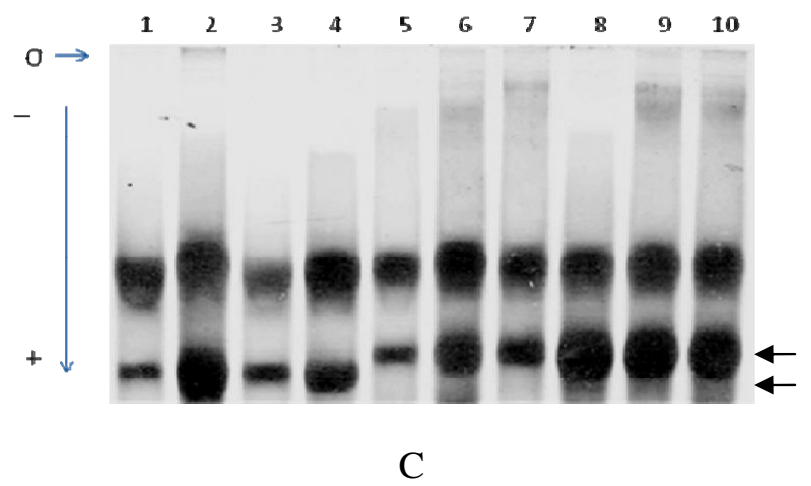

\section{Figure 2}

A. Zymogram of Superoxide dismutase (Sod-I). Lanes I, 2 M. booduga (M); Lanes 3, 4 M. booduga (V); Lanes 5, 6 M. terricolor I; Lanes 7, 8 M. terricolor II; Lanes 9, 10 M. terricolor III. Lanes I to 4 show bands of faster mobility (Sod- Ib) in M. booduga. B. Electrophoregram of serum Tranferrin (Trf). Lanes I, 2 M. booduga (M); Lanes 3, 4 M. booduga (V); Lanes 5, 6 M. terricolor I; Lanes 7, 8 M. terricolor II; Lanes 9, 10 M. terricolor III. Lanes I to 4 (arrow) show faster allele in M. booduga. Samples in lanes 2, 3 are heterozygotes. C. Electrophoregram of Hemoglobin beta chain (Hbb). Lanes I, 2 M. booduga (M); Lanes 3, 4 M. booduga (V); Lanes 5, 6 M. terricolor I; Lanes 7, 8 M. terricolor II; Lanes 9, 10 M. terricolor III. Samples in lanes I to 4 show major band of faster mobility (arrow) in M. booduga. 
Table 2: Allele frequencies at $\mathrm{Hbb}$, Trf and Sod-I loci in the Indian pygmy field mice with sample size in parenthesis.

\begin{tabular}{|c|c|c|c|c|c|}
\hline & M. booduga (M) & M. booduga $(V)$ & M. terricolor I & M. terricolor II & M. terricolor III \\
\hline$H b b^{p}$ & 0.067 & --- & 1.000 & 1.000 & 1.000 \\
\hline$H b b^{b}$ & 0.933 & 1.000 & --- & --- & --- \\
\hline$N$ & $(15)$ & (19) & (18) & (I5) & (19) \\
\hline $\operatorname{Tr} f^{a}$ & 0.929 & 0.963 & --- & --- & --- \\
\hline $\operatorname{Tr} f^{b}$ & 0.071 & 0.037 & --- & --- & --- \\
\hline $\operatorname{Tr} f^{c}$ & --- & --- & 0.962 & 0.913 & 0.904 \\
\hline $\operatorname{Tr} f^{d}$ & --- & --- & 0.038 & 0.087 & 0.096 \\
\hline$N$ & $(28)$ & $(27)$ & $(26)$ & $(23)$ & $(26)$ \\
\hline Sod- $I^{a}$ & --- & --- & 1.000 & 1.000 & 1.000 \\
\hline Sod- $I^{b}$ & 1.000 & 1.000 & --- & --- & --- \\
\hline $\mathrm{N}$ & $(13)$ & $(26)$ & $(12)$ & (II) & $(12)$ \\
\hline
\end{tabular}

ences in molecules related to hypoxic tolerance like hemoglobin, myoglobin, erythropoietin, VEGF, etc. in subterranean mole rats Spalax [14]. Also, evidence from a number of high-altitude vertebrates viz., North American deer mice (Peromyscus maniculatus) living in hypoxic conditions indicates that modifications of hemoglobin function typically play a key role in mediating an adaptive response to chronic hypoxia $[19,20]$.

Interestingly, the electrophoretic analysis in the present study showed difference in mobility and fixation of alternative alleles at three loci Hbb, Trf and Sod-1 that are directly or indirectly dependent on oxygen concentration for function, between sibling species $M$. booduga and $M$. terricolor. In M. booduga the fixed alleles of all the three loci are of faster mobility. An increased anodal mobility of the major component of $\mathrm{Hbb}$ has been reported which is associated with increased oxygen affinity [21]. In the serum faster migrating transferrin binds more iron atoms than the slower transferrin, and iron is one of the important components of hemoglobin [22]. Superoxide radical anion is formed even as a normal product of the biological reduction of molecular oxygen. The superoxide dismutase protects organisms against oxygen toxicity by catalyzing dismutation of the reactive radical to hydrogen peroxide and oxygen. Peng et al., [23] have shown in Xirradiated Drosophila melanogaster that the allele of slow mobility (S) had higher enzyme activity which provided more protection against radiation damage than allele of fast mobility (F). Their results further indicated a possible adaptive role of the polymorphism (S/F) found in natural populations of $D$. melanogaster. If this could be extrapolated, the allele of faster mobility (Sod-1 ${ }^{\mathrm{b}}$ ) present in $M$. booduga may presumably be adapted to an environment with less oxygen in their nests and burrows. Working on the subterranean system Spalax, Israeli scientists at University of Haifa are now focusing on whether these rodents could help understand and treat human diseases involving hypoxia [24].

\section{Conclusion}

Thus, location, structure and depth of the burrows might have been the contributory factors for selection of alternative alleles at three loci Sod-1, Trf and Hbb (the molecules related to hypoxic tolerance), which reflect differences in probable adaptive strategy in M. booduga and M. terricolor. The burrows of the non-overlapping chromosomal species $M$. terricolor I, II and III are however the same which could be due to recency of their evolutionary divergence, but more so because of lack of competition for the welladapted 'microhabitats' as they are non-overlapping in distribution, unlike between the co-existing, sibling species $M$. booduga and M. terricolor which exhibit mutual "exclusion" of the 'microhabitats' for burrow construction.

Further, understanding the biochemical mechanisms that enable the subterranean rodents to survive and function under conditions of hypoxic stress can provide important insights into the nature of physiological adaptations. The Indian pygmy field mice are a unique model system to study molecular mechanisms for adaptation to hypoxia. The importance of adaptation to hypoxia in understanding the behavior of several biological systems is coming to the fore.

\section{Methods}

Burrow study

Live burrows in rice and wheat fields were studied by carefully excavating them during breeding seasons which coincided with harvesting of the major crops. Studies of live burrows of $M$. booduga were done from Varanasi in northern India (81 metres above sea level) and Mysore, Erode (770 metres above sea level in between the Eastern 
and Western ghats, towards south) and Chennai (east side of Eastern ghats 8 metres above sea level) in southern India. Likewise, live burrows of the apparently non-overlapping chromosomal species M. terricolor I, II and III were dug up in cultivated fields from Varanasi, Mysore and Chennai. The lengths of the inlet and outlet tunnels, depth of nest chamber and the diameters of nests and inlet/outlet tunnels were measured with precision using measuring tape recorded to the nearest $1 \mathrm{~cm}$.

\section{Electrophoresis}

Tissue sample preparation, buffer systems and stains were similar to those described by Selander et al. [25] and Harris and Hopkinson [26]. Equal amounts of protein (estimated by the method of Lowry et al. [27]) were loaded. Tissue sources were liver for superoxide dismutase (Sod$1)$, serum for transferrin (Trf) and hemolysate for hemoglobin beta-chain (Hbb). Proteins were resolved on $7.5 \%$ polyacrylamide vertical gel. Hemoglobin beta-chain haplotypes were scored according to the method of Morton [28] and transferrin genotypes were scored according to Cohen [29]. Electrophoresis for all the three loci was carried for 4 to 5 hours at a constant $250 \mathrm{~V}$ at $4{ }^{\circ} \mathrm{C}$. For electrophoretic study, M. booduga mice were collected from Varanasi and Mysore, and M. terricolor I, II and III mice were collected from Varanasi, Mysore and Chennai, respectively. This study has been approved by the institutional ethical committee of Banaras Hindu University.

\section{Authors' contributions}

The study was conceived and planned by TS, the electrophoretic study, data analysis and manuscript preparation was carried out by SS and GN, and NC studied the burrow patterns. All authors have read and approved the manuscript.

\section{Acknowledgements}

Financial support to TS from Council of Scientific and Industrial Research, India and SS by UGC is acknowledged.

\section{References}

I. Matthey R, Petter F: Existence de deux especes l'une chromosomiquement polmorphe, chez des Mus Indiens du groupe booduga. Etude cytogenetique et taxonomique. Rev Suisse de Zool 1968, 75:461-498.

2. Sen S, Sharma T: Role of constitutive heterochromatin in evolutionary divergence: Results of chromosome banding and condensation inhibition studies in Mus musculus, Mus boobuga and Mus dunni. Evolution 1983, 37:628-636.

3. Sharma T, Cheong N, Sen P, Sen S: Constitutive heterochromatin and evolutionary divergence of Mus dunni, Mus booduga, and Mus musculus. Curr Top Microbiol Immunol I 986, I 27:35-44.

4. Chatterjee $B$, Bahadur M, Sharma T: Mitochondrial DNA restriction maps of Mus booduga, Mus terricolor and Mus musculus tytleri. J Genet 1994, 73:57-64.

5. Sharma T: Chromosomal and molecular divergence in the Indian pygmy field mice $M$. booduga-terricolor lineage of the subgenus Mus. Genetica 1996, 97:331-338.

6. Singh S, Sharma T: High levels of genetic variations in Indian field and house mice. J Genet 1997, 76: 189-200.
7. Sharma GG, Sharma T: Unusual chromosomal organization of telomeric sequences and expeditious karyotipic differentiation in the recently evolved Mus terricolor complex. Cytogenet Cell Genet 1998, 80:204-208.

8. Estep DQ, Lanier DL, Dewsbury DA: Copulatory behaviour and nest building behaviour of wild house mice (Mus musculus). Anim Learn Behav 1975, 3:329-336.

9. Wolfe JL, Barnett SA: Effects of cold on nest-building by wild and domestic mice, Mus musculus L. Biol J Linn Soc 1977, 9:73-85.

10. McNab B: The metabolism of fossorial rodents: a study of convergency. Ecology 1966, 47:712-733.

II. Arieli R, Nevo E: Hypoxic survival differs between two mole rat species (Spalax ehrenbergi) of humid and arid habitats. Comp Biochem Physiol 1991, A 1 00:543-545.

12. Nevo E, Ivanitskaya E, Beiles A: Adaptive radiation of Blind Subterranean Mole rat. Backhuys, Leiden $200 \mathrm{I}$.

13. Shams I, Avivi A, Nevo E: Hypoxic stress tolerance of the Blind Subterranean Mole rat: Expression of erythropoietin and hypoxia-inducible factor I alpha. Proc Natl Acad Sci, USA 2004, | 0 l:9698-9703.

14. Shams I, Nevo E, Avivi A: Erythropoietin receptor spliced forms differentially expressed in blind subterranean mole rats. FASEB J 2005, 19:307-309.

15. Russel EW: Soil conditions and plant growth English Language Book Society; I96I.

16. Baver L, Gardner W, Gardner W: Soil Physics Wiley, New York; 1972.

17. Maclean G: Factors influencing the composition of respiratory gases in mammal burrows. Comp Biochem Physiol 1981, A84:517-522.

18. McNab B: The physiological ecology of vertebrates-A view from energetic Cornell University Press, New York; 2002.

19. Weber RE, Fago A: Functional adaptation and its molecular basis in vertebrate hemoglobins, neuroglobins and cytoglobins. Respir Physiol Neurobiol 2004, 144: |41-159.

20. Storz JF: Hemoglobin function and physiological adaptation to hypoxia in High-Altitude mammals. J Mammal 2007, 88:24-3I.

21. Peters ML, Andrews SJ, Loutit JB: A mouse beta-globin mutant that is exact model of hemoglobin rainer in man. Genetics 1985, I 1 0:709-72I.

22. Giblett ER, Hickman CG, Smithies O: Serum transferrin. Nature 1959, I 83:1589-I590.

23. Peng TX, Moya A, Ayala FJ: Irradiation-resistance conferred by superoxide dismutase: Possible adaptive role of a natural polymorphism in Drosophila melanogaster. Proc Natl Acad Sci, USA 1 986, 83:684-687.

24. Anitei S: How to resist the lack of oxygen? The blind mole rat gives the answer. [http://news.softpedia.com/news/How-to-
[ Resist-the-Lack-of-Oxygen-45014.shtml].

25. Selander RK, Smith MG, Yang SY, Johnson WE, Gentry JB: Biochemical polymorphism and systematic in the genus Peromyscus. I. Variation in the old field mouse (Peromyscus polionotus). Studies Genet I 97I, 7 I 03:49-90.

26. Harris H, Hopkinson DA: Handbook of enzyme electrophoresis in human genetics North Holland: Amsterdam; 1976.

27. Lowry OH, Rosebrough NJ, Farr Al, Randall RJ: Protein measurement with the Folin Phenol Reagent. J Biol Chem 1951, 1 93:265-275.

28. Morton JR: The multiple electrophoretic bands of mouse hemoglobins. Genet Res, Cambridge 1966, 7:76-85.

29. Cohen BL: Genetics of plasma transferrins in the mouse. Genet Res, Cambridge 1960, I:431-438. 